\title{
Immunocytotoxic Effect of Aqueous Leaf Extract of Cassia occidentalis on Human Peripheral Blood Mononuclear Cells and Neutrophils
}

\author{
${ }^{1}$ Hamid, K. M. (D), '1Yakubu, A., ${ }^{1}$ Sani, S. A., ' Kalgo, M. U., ${ }^{1}$ Isiyaku, A., ${ }^{1}$ Umahi, N. P. F., \\ ${ }^{1}$ Garba, Y. B., ${ }^{2 *}$ Aliyu, M. (iD), ${ }^{3}$ Isah, S. Y. (i), ${ }^{4}$ Abubakar, U. \\ ${ }^{1}$ Department of Immunology, School of Medical Laboratory Sciences, Usmanu Danfodiyo University, \\ P.M.B. 2346, Sokoto, Nigeria \\ 2 Department of Medical Microbiology and Parasitology, Faculty of Clinical Sciences, College of \\ Health Sciences, Bayero University. P.M.B. 3011, Kano, Nigeria \\ ${ }^{3}$ Department of Medical Laboratory Science, Faculty of Allied Health Sciences, Bayero University. \\ P.M.B. 3011, Kano, Nigeria \\ ${ }^{4}$ Department of Histopathology, School of Medical Laboratory Sciences, Usmanu Danfodiyo \\ University, Sokoto, P.M.B. 2346, Sokoto, Nigeria. \\ *Corresponding author: maliyu.med@buk.edu.ngTelephone number:+234 8038468616
}

\section{Authors' ORCIDs:}

Abstract
The study evaluates the potential immunocytotoxic effect of aqueous leaf extract of Cassia occidentalis on human peripheral blood mononuclear cells (PBMCs) and Neutrophils. Different concentrations $(25 \mu \mathrm{g} / \mathrm{ml}, 50 \mu \mathrm{g} / \mathrm{ml}, 100 \mu \mathrm{g} / \mathrm{ml})$ of the extract were prepared. Six millilitres $(6 \mathrm{ml})$ of peripheral blood from consented healthy volunteers was collected and PBMCs and neutrophils were isolated on Histopaque media. The viability of PBMCs and neutrophils was determined using trypan blue dye exclusion methods. One-way analysis of variance was used in analysing the results. Total viable cell count (TVCC) for PBMCs and neutrophils yielded $298.9 \times 10^{4}$ cells $/ \mathrm{ml}$ and $327.9 \times 10^{4}$ cells $/ \mathrm{ml}$ respectively. The TVCC of the highest concentration $(100 \mu \mathrm{g} / \mathrm{ml})$ of the extract used for the treatment of PBMCs was $192.7 \times 104$ cells $/ \mathrm{ml}$ and that of neutrophil was $50.47 \times 10^{4}$ cells $/ \mathrm{ml}$ equivalent to $82.51 \%$ and $61.71 \%$ mean viability percentages respectively. The PBMCs and neutrophils treated with $25 \mu \mathrm{g} / \mathrm{ml}$ of the extract have the highest mean percentage viability scores of $94.88 \%$ and $74.61 \%$ respectively. There was a significant difference in the mean percentage viability when control PBMCs was compared with those treated with 100 $\mu \mathrm{g} / \mathrm{ml}(\mathrm{p}<0.0001)$ and also when control neutrophils was compared with those treated with $25 \mu \mathrm{g}$ $/ \mathrm{ml}(\mathrm{p}=0.02), 50 \mu \mathrm{g} / \mathrm{ml}$ and $100 \mu \mathrm{g} / \mathrm{ml}(\mathrm{p}<0.0001)$ respectively. The cell viability tends to decrease in a dose-dependent manner. The aqueous leaf extract of $C$. occidentalis has a potent cytotoxic effect on both cells, especially at a higher dose. The study recommends an in-depth study to improve the credence of the present study findings.

Keywords: Cassia occidentalis extract, Cytotoxic activity, Human Neutrophils and PBMCs.

\section{INTRODUCTION}

Humans perpetually use medicinal plants for the treatment of disease conditions as well as other pharmacological applications on animals (Ghani, 1998). The drugs sourced from plant materials are becoming popular globally in health care settings (Bashir et al., 2015). The phytoconstituents differs among the different parts of the plant materials wereuse based on purpose (Rahman et al., 2013). Some of the reported chemical constituents are tannins, alkaloids, volatile oils, minerals, vitamins, Besides, every part of the $C$. occidentalis plant was used for different purposes (Sini et al., 2010) and several studies indicate its application in different disease conditions. For glycosides, among others (Srivastava, 2003). However, natural products have some limitations based on their potency, safety and dose due to the paucity of reliable data (Jowell, 1999). Therefore, safety is one of the critical factors to consider before using plant materials to avoid potential adverse reactions (Shah et al., 2013).

Cassia occidentalis was recognized as one of the widely accepted medicinal plants in traditional medicine, as it yields the desired effect (Yakubu et al., 2007). instance, it is used as a poison antidote, blood purifier, expectorant, anti-inflammatory agent and a remedy for the treatment of liver diseases (Vijayalakshmi et al., 2013). Other 
UJMR, Volume 6 Number 2, December, 2021, pp 30 - $36 \quad$ ISSN: 2616 - 0668

uses include anti-microbial agent (Sadiq et al., 2012), antioxidant (Daniyan et al., 2011), immunosuppressive and larvicidal (Abirami et al., 2011) or in wound healing (Garba et al., 2015), sores, itch, cutaneous diseases, bone fracture, fever, ringworm, skin diseases, throat infection (Arya et al., 2010) to mention but a few. Local communities are using the fresh leaves of the plant without prior knowledge of its effect on the body, thus necessitate an effort to assess its safety (Berinyuy et al., 2015).

Presumably, the $C$. occidentalis may affect the immune system, based on its ability to triggers anti-inflammatory response with consequent production of anti-inflammatory cytokines (Koffuor et al., 2016). The immune system protects the body against invading microorganisms (Bomford, 2010). It comprises several cells and cells secretion that identify and neutralize an unlimited number of threats (Naga et al., 2014). Peripheral blood mononuclear cells (PBMCs) are a group of blood cells that possess a round nucleus and function to protect the body against infections. These major cells of the immune system consist of lymphocytes, monocytes, or macrophages. Neutrophils are one of the most popular groups of cells out of many that scout to protect against microbes; they are indispensable in the immune system (Kruger et al., 2015).

A report shows that the $C$. occidentalis contain phytotoxins (Rekha et al., 2016). Accordingly, the plants may be toxic to the immune cells, as exposure of immune cells to the toxic compounds may lead to a decrease in cell viability and cell death (Sudeep et al., 2017). Indeed, a study has indicated, the use of plant extracts in high dose could lead to toxic injury to the kidneys, liver, intestine and immune cells, which interfere with normal biological functions (Mainasara et al., 2016). Most of the previous studies concentrate on medicinal uses, application or properties of the plants in different research models (Kangiwaet al., 2017; Tochukwu et al., 2018).

Of note, people consume the extract of C. occidentalis for treatment of many bacterial and fungal infections; but are ignorant of the concentration they ingested. The information on human PBMCs and neutrophils viability after exposure to aqueous leaves extract of C. occidentalis is scarce. Consequently, this study focused on the potential immunocytotoxic effect of aqueous leaves extract of $C$. occidentalis on human PBMCs and neutrophils. This will serve as another concerted effort to provide much-needed information on this important plant.

\section{MATERIALS AND METHODS}

\section{Plant Collection and Identification}

Fresh leaves of $C$. occidentalis were collected locally. The plant taxonomic identification and assigning of specimen voucher numbers were carried out at the Department of Botany, Usmanu Danfodiyo University Sokoto, Nigeria. The voucher number assigned was UDUH/ANS/0110.

\section{Preparation of Plants Materials}

Fresh leaves of $C$. occidentaliswerewashed thoroughly, shade-dried, coarsely powdered using mortar and pestle and then sieved. Subsequently, $1300 \mathrm{~g}$ of the dried powder was dissolved in $7 \mathrm{~L}$ of distilled water. We left thepreparation to soak for 24 hours in a water bath set at $40^{\circ} \mathrm{C}$. Then we filtered the preparation using Whatman No. 1 filter paper. The resultant filtrate was concentrated to dryness at $40^{\circ} \mathrm{C}$ under reduced pressure (Gadanya and Muhammad, 2018). A weighing quantity of $0.1 \mathrm{~g}$ of the dried extract was dissolved in $1 \mathrm{ml}$ of distilled water, and this served as the stock.

\section{Blood Sample Collection and Processing}

Six millilitres $(6 \mathrm{ml})$ of whole blood was collected from consented healthy volunteer using the Monovette vacutainer system and sample collected was transferred into a labelled lithium heparin tube, and mixed properly-the blood sample was used for isolation of human PBMCs and neutrophils.

Isolation of PBMCs and Neutrophils

The procedure was carried out according to the manufacturers' instructions. Briefly, $3 \mathrm{ml}$ of Histopaque-1119 (Sigma-Aldrich ${ }^{\circledR}$ Co. UK) was added to a $15 \mathrm{ml}$ conical centrifuge tube. Subsequently, $3 \mathrm{ml}$ of Histopaque-1077 (SigmaAldrich $₫$ Co. UK) was carefully layered onto the Histopaque-1119 and brought to room temperature. Carefully $6 \mathrm{ml}$ of whole blood was layered onto the upper gradient of the two different density Histopaques and centrifuged at $700 \times \mathrm{g}$ for 30 minutes at room temperature. PBMCs were obtained from the first layer (onto Histopaque 1077), and neutrophils were isolated from the second buffy coat layer (onto Histopaque 1119). The cells were then washed twice with RPMI 1640 (Sigma-Aldrich ${ }^{\circledR}$ Co. UK) at $200 \times \mathrm{g}$ for 10 minutes. The cells were resuspended in $2 \mathrm{ml}$ of RPMI 1640 media each and immediately used.

\section{PBMCs and NeutrophilsCount (Trypan blue assay)}

The cells were counted using a haemocytometer, $10 \mu \mathrm{l}$ of $0.4 \%$ Trypan Blue (Lobal Chemie Mumbai, India) solution (w/v) 


\section{UJMR, Volume 6 Number 2, December, 2021, pp 30 - $36 \quad$ ISSN: 2616 - 0668}

was dispensed into a $2 \mathrm{ml}$ Eppendorf tube then $10 \mu \mathrm{l}$ of each of the PBMCs and the neutrophil suspension was added into different tubes (dilution factor $=2$ ) and mixed thoroughly, the mixture was allowed to stand for 5 minutes. With the cover slip in place, the pipette was used to transfer $10 \mu \mathrm{l}$ of the Trypan blue-cells suspension mixture to both chambers of the haemocytometer. Both the viable and nonviable cells were counted using a microscope. Non-viable cells are stained blue, whereas viable ones remain colourless. The percentage of viable cells was calculated.

\section{Treatment of PBMCs and Neutrophils with} Plant Extract

Ten sets of $2 \mathrm{ml}$ falcon tubes, five for each PBMCs and Neutrophils, were placed in a tube rack. And into each tube $50 \mu \mathrm{l}$ of PBMCs (298.9 x $10^{4}$ cells $\left./ \mathrm{ml}\right)$ or neutrophils $\left(327.9 \times 10^{4}\right.$ cells $/ \mathrm{ml}$ ) suspension was dispensed then $50 \mu \mathrm{l}$ of each of the following concentration 25 $\mu \mathrm{g} / \mathrm{ml}, \quad 50 \mu \mathrm{g} / \mathrm{ml}$ and $100 \mu \mathrm{g} / \mathrm{ml}$ of the $C$. occidentalis plant extract were added into the tubes respectively. The tubes labelled appropriately were incubated at $37^{\circ} \mathrm{C}$ for 30 minutes in an incubator. A tube containing the PBMCs or neutrophils suspended in RPMI 1640 media without plant extract was considered as the control. All the treatments were carried out in duplicate (Sudeep et al., 2017). Cell count was carried out using Trypan blue assay after the incubation as described above.

\section{Statistical Analysis}

The data obtained were entered into SPSS version 21 (IBM, USA) for analysis. Continuous variables are expressed as mean and standard deviation (SD) or mean percentage. One-way between-groups analysis of variance (ANOVA) with Post-hoc Test (Bonferroni) was carried out to compare the different concentrations of the extract. The $p$-value of $\leq 0.05$ was used to determine the level of statistical significance.

\section{RESULTS}

\section{PBMCs and Neutrophils Count}

The total viable cell count (TVCC) of PBMCs immediately after isolation was $298.9 \times 10^{4}$ cells $/ \mathrm{ml}(\mathrm{SD}=2.91)$. The total viable cell count of neutrophils immediately after isolation was $327.9 \times 10^{4}$ cells $/ \mathrm{ml} \quad(S D=1.07)$. The mean percentage viability scores of PBMCs and neutrophils before treatment were $96.00 \%$ and $96.56 \%$ respectively. As depicted from Table 1 , the TVCC of the control PBMCs was $273.1 \times 10^{4}$ Post-hoc comparisons using Bonferroni tests showed that there was a-significant difference in mean percentage viability score when cells $/ \mathrm{ml}(\mathrm{SD}=4.32)$. The TVCC of the lowest concentration $(25 \mu \mathrm{g} / \mathrm{ml})$ of the $C$ occidentalis extract used for the treatment of PBMCs was $204.8 \times 10^{4}$ cells $/ \mathrm{ml}(\mathrm{SD}=5.02)$ that of the highest concentration $(100 \mu \mathrm{g} / \mathrm{ml})$ was $192.7 \times 10^{4}$ cells $/ \mathrm{ml}(\mathrm{SD}=6.33)$. From Table 2 , the TVCC of control neutrophils was $257.7 \times 10^{4}$ cells $/ \mathrm{ml}$ $(S D=9.14)$. The TVCC of the lowest concentration $(25 \mu \mathrm{g} / \mathrm{ml})$ of the $C$. occidentalis extract used for the treatment of Neutrophils was $143.9 \times 10^{4}$ cells $/ \mathrm{ml}(S D=6.43)$ that of the highest concentration $(100 \mu \mathrm{g} / \mathrm{ml})$ was 50.47 $\mathrm{x} 10^{4}$ cells $/ \mathrm{ml}(\mathrm{SD}=1.57)$.

Effect of the $C$. occidentalis Extracts on PBMCs.

As shown in Table 1, the mean percentage viability scores of control PBMCs was $95.16 \%$. Those PBMCs treated with $25 \mu \mathrm{g} / \mathrm{ml}$ of the extract have the highest mean percentage viability scores of $94.88 \%$, while the least TVCC was among the PBMCs treated with $100 \mu \mathrm{g} / \mathrm{ml}$ of the $C$. occidentalis extract $(82.51 \%)$. Analysis of variance (ANOVA) revealed that there was a significant difference in human PBMCs' mean percentage viability scores across the different concentrations of the $C$. occidentalis extract $(25 \mu \mathrm{g} / \mathrm{ml}, 50 \mu \mathrm{g} / \mathrm{ml}, 100 \mu \mathrm{g} / \mathrm{ml})$ as well as control $(p<0.0001)$. Post-hoc comparisons using the Bonferroni tests indicated that there was no significant difference in mean percentage viability score between control PBMCs and those treated with $25 \mu \mathrm{g} / \mathrm{ml}$ and $50 \mu \mathrm{g} / \mathrm{ml}$ of the $C$. occidentalis extract $(p>0.05)$. However, there was a-significant difference in the mean percentage viability score when control PBMCs were compared with those treated with $100 \mu \mathrm{g}$ $/ \mathrm{ml}(p<0.0001)$.

\section{Effect of the $C$. occidentalis Extracts on}

Neutrophils.

However, from Table 2, the mean percentage viability scores of control neutrophils were $95.31 \%$. Those neutrophils treated with 25 $\mu \mathrm{g} / \mathrm{ml}$ of the $C$. occidentalis extract have the highest mean percentage viability scores of $74.61 \%$, while the least was among the neutrophils treated with $100 \mu \mathrm{g} / \mathrm{ml}$ of the extract $61.71 \%$. Analysis of variance (ANOVA) revealed that there was a-significant difference in human neutrophils mean percentage viability scores across the different concentrations of the extract $(25 \mu \mathrm{g} / \mathrm{ml}, 50 \mu \mathrm{g} / \mathrm{ml}, 100 \mu \mathrm{g} / \mathrm{ml})$ as well as control $(p<0.0001)$.

control neutrophils were compared with those treated with $25 \mu \mathrm{g} / \mathrm{ml}$ ( $p=0.02$ ), $50 \mu \mathrm{g} / \mathrm{ml}$ and $100 \mu \mathrm{g} / \mathrm{ml}(p<0.0001)$ respectively. 
Table 1: Effect of different concentrations of the C. occidentalis extract on PBMCs viability

C. occidentalis Extract

Concentration $(\mu \mathrm{g} / \mathrm{ml})$
TVCC $\times 10^{4}$ cells $/ \mathrm{ml}$

Mean (SD)

Control

25

50

100

$273.1(4.32)$

$204.8(5.02)$

$185.4(3.97)$

$192.7(6.33)$

PBMCs

Mean viability (\%)

$p$-value

$\begin{array}{ll}95.16 & <0.0001 \\ 94.88 & \\ 93.47 & \\ 2.511^{\text {at+o* }} & \end{array}$

TVCC: Total viable cell counts, $\mathrm{a}=$ Control vs. $100 \mu \mathrm{g} / \mathrm{ml},{ }^{* *+*} \mathrm{p}<0.0001$

Table 2: Effect of different concentrations of the C. occidentalis extract on neutrophils viability

\begin{tabular}{|c|c|c|c|}
\hline \multirow{2}{*}{$\begin{array}{l}\text { C. occidentalis Extract } \\
\text { Concentration } \\
(\mu \mathrm{g} / \mathrm{ml})\end{array}$} & \multicolumn{3}{|c|}{ Neutrophils } \\
\hline & $\begin{array}{c}\text { TVCC } \times 10^{4} \text { cells } / \mathrm{ml} \\
\text { Mean }(\mathrm{SD})\end{array}$ & Mean viability (\%) & $p$-value \\
\hline Control & $257.7(9.14)$ & 95.31 & $<0.0001$ \\
\hline 25 & $143.9(6.43)$ & $74.61^{\mathrm{a}^{* *}}$ & \\
\hline 50 & $72.33(3.53)$ & $72.31^{b^{* * *}}$ & \\
\hline 100 & $50.47(1.57)$ & $61.71^{\mathrm{c}^{* * *}}$ & \\
\hline
\end{tabular}

TVCC: Total viable cell counts, $a=$ Control vs. $25 \mu \mathrm{g} / \mathrm{ml}, \mathrm{b}=$ Control vs. $50 \mu \mathrm{g} / \mathrm{ml}, \mathrm{c}=$ Control vs. 100 $\mu \mathrm{g} / \mathrm{ml},{ }^{* *} \mathrm{p}=0.02,{ }^{* * *} p<0.0001$,

\section{DISCUSSION}

Assessment of the cytotoxic potential of compounds in medicinal plants intended for therapeutic use is mandatory to establish drug safety (Teixeira et al., 2003). Cytotoxic compounds kill living cells through insidious genetically organized mode termed apoptosis, or through haphazard rapid disintegrative modus operandi: necrosis (Çelik, 2018). Researchers employed different methodologies for the assessment of cytotoxicity among living cells (Niles et al., 2007). Medicinal plants with cytotoxic potential stand a chance in cancer therapy (Anantachoke et al., 2020).

This study shows that the TVCC as well as mean percentage cell viability, tends to decreased with an increased in concentrations of $C$. occidentalis plant extract for both PBMCs and neutrophils. This suggests C. occidentalis possess the dose-dependent cytotoxic effect on the PBMCs and neutrophils. This study demonstrated that the mean percentage viability of PBMCs and neutrophils before treatment and among control cells were within the reported range as the normal cell viability was $90-95 \%$ as highlighted by earlier researches (Chahra et al., 2016; Kalgo et al., 2019; Kalgo et al., 2020).

While comparing the mean percentage viability scores between groups, we observed no Our result findings are in line with Sudeep et al. (2017) which reported cytotoxicity on human lymphocytes after treatment with three different plant extract in-vitro. Kalgo et al. (2020) reported a cytotoxic effect on human UMYU Journal of Microbiology Research significant difference between low dose extract $(25 \mu \mathrm{g} / \mathrm{ml}$ and $50 \mu \mathrm{g} / \mathrm{ml})$ and control for PBMCs. On the other hand, significant differences exist at the highest extract dose concentration (100 $\mu \mathrm{g} / \mathrm{ml}$ ) in both cell groups. The indifferences may be attributed to the low doseconcentration effect of the $C$. occidentalis plant extract on the cells as such do not exert significant cytotoxicity. In-vitro toxicity profile of the $C$. occidentalis extract might be safe for use up to a defined effective concentration (Lombardo et al., 2015).

Despite the profound therapeutic advantages possessed by some of the medicinal plants, some constituents of medicinal plants are potentially toxic (Akintonwa et al., 2009). Indeed, drugs of plant origin are not free from toxic effects (Edziri et al., 2011). The cytotoxicity witnessed on the PBMCs and neutrophils may be because of some chemical constituents that $C$. occidentalis leaves contain which exerts cytotoxic effects at specific concentrations. The presence of anthraquinones, emodin, glycosides, toxalbumin, and other alkaloids contained in C. occidentalis can explain the encountered toxicity (Al-Snafi, 2014). Cytotoxic compounds kill live cells (Sudeep et al., 2017).

PBMCs after treatment with a high concentration of aqueous stem back extract of Vitellaria paradoxa. Boudoukha et al. (2016) reported dose-dependent-elastase inhibition, degranulation, phagocytosis, and chemotaxis of www.ujmr.umyu.edu.ng 
neutrophils when exposed to Santolina chamae cyparissus extract. Similarly, attenuation of neutrophil recruitment and lowered myeloperoxidase activity in a murine study were observed when exposed to Phytol (Silva et al., 2014) or Passiflorasub peltata plant extracts (Shanmugam et al., 2020).

Neutrophils viability decrease with increasingconcentration of stem back extracts of Vitellaria paradoxa (Kalgo et al., 2019). However, Patil et al. (2010) revealed the immunostimulatory effect of neutrophils upon exposure to Bauhinia variegata Linn bark extract. An in-vitro study showed that C. occidentalis act as an immunosuppressant on immune cells (PBMCs and neutrophils), and the plant extract treatment itself produced toxicity (Vijayabhaskar et al., 2013). Indeed, the use of other cells viability assays would improve the credence of our findings.

REFERENCES

Abirami, D. and Murugan, K. (2011). HPTLC quantification of flavonoids, larvicidal and smoke repellent activities of Cassia occidentalis L. (Caesalpiniaceae) against malarial vectore Anopheles stephensi Lis (Diptera: Culicidae). Journal of Phytology, 3(2), 60-71.

Akintonwa, A., Awodele, O., Afolayan, G., Coker, H.a.B. (2009). Mutagenic screening of some commonly used medicinal plants in Nigeria. Journal of Ethnopharmacology, 125(3), 461-470.

Al-Snafi, A.E. (2014). The pharmacological activities of Alpinia galangal-A review. International Journal for Pharmaceutical Research Scholars, 3(11), 607-614.

Anantachoke, N., Lovacharaporn, D., Reutrakul, V., Michel, S., Gaslonde, T., Piyachaturawat, P., Suksen, K., Prabpai, S., Nuntasaen, N. (2020). Cytotoxic compounds from the leaves and stems of the endemic Thai plant Mitrephora sirikitiae. Pharmaceutical biology, 58(1), 490-497.

Arya, V., Yadav, S., Kumar, S., Yadav, J. (2010). Antimicrobial activity of Cassia occidentalis $\mathrm{L}$ (leaf) against various human pathogenic microbes. Life Sciences and Medicine Research, 9(1), e12.

Bashir, L., Shittu, O., Busari, M., Sani, S., Aisha, M. (2015). Safety Evaluation of Giant African Land Snails (Archachatina maginata) Haemolymph on Hematological and Biochemical Parameters of Albino Rats. Journal of

\section{CONCLUSION}

The study revealed a significant decrease in PBMCs and neutrophils viability when exposed to a higher concentration of Cassia occidentalis plant extract but recorded an insignificant decrease in cellular viability of PBMCs at a lower concentration. This suggests potential immunocytotoxicity with more effect at higher concentration. However, there is a need for indepth study on the effect of $C$. occidentalis on human PBMCs and neutrophils. Notwithstanding, cytotoxicity studies on organ systems starting at a murine level can give more insight.

\section{Conflict of Interest}

Authors declare no conflict of interest

\section{Funding}

This research did not receive any funding.

Advances in Medical and Pharmaceutical Sciences, 3(3), 122-130. Berinyuy, E., Lawal, B., Olalekan, L., Olalekan, I., Yusuf, A., Sakpe, S., Ossai, P. (2015). Hematological Status and Organs/Body-weight Parameters in Wister Rats during Chronic Administration of Cassia occidentalis. International Blood Research and Reviews, 4(3), 1-7.

Bomford, R. (2010). Ethnomedicine: A Source of Complementary Therapeutics. Research Signpostt, 159, 227-244.

Boudoukha, C., Bouriche, H., Ortega, E., Senator, A. (2016). Immunomodulatory effects of Santolina chamaecyparissus leaf extracts on human neutrophil functions. Pharmaceutical biology, 54(4), 667-673.

Çelik, T.A. (2018). Introductory Chapter, In: Çelik, T.A. (ed). Cytotoxicity. IntechOpen Limited, 5 Princes Gate Court, London, SW7 2QJ, UK.

Chahra, D., Ramdani, M., Lograda, T., Chalard, P., and Figueredo, G. (2016). Chemical composition and antimicrobial activity of Evernia prunastri and Ramalina farinacea from Algeria. Issues in Biological Sciences and Pharmaceutical Research 4(5), 35-42.

Daniyan, S., Oloruntimelehin, J., and Ifeadi, 0. (2011). Antibacterial activity of Cassia occidentalis flower vegetable extract on selected bacteria. Asian Journal of Biomedical and Pharmaceutical Sciences 1(1).

Edziri, H., Mastouri, M., Mahjoub, A., Anthonissen, R., Mertens, B., 
Cammaerts, S., Gevaert, L., Verschaeve, L. (2011). Toxic and mutagenic properties of extracts from Tunisian traditional medicinal plants investigated by the neutral red uptake, VITOTOX and alkaline comet assays. South African Journal of Botany, 77(3), 703-710.

Gadanya, A. and Muhammad, S. (2018). Hypolipidemic effect of oral administration of aqueous leaf extract of Senna occidentalis in rats. Nigerian Journal of Basic and Clinical Sciences, $15(1), 68$.

Garba, R., Saidu, A., Adeyemi, H., and Muhammad, H. (2015). Effect of methanolic extract of Cassia occidentalis $\mathrm{L}$. root bark on body weight and selected biochemical parameters in alloxan induced diabetic rats. British Journal of Pharmacology and Toxicology 6(2), 39-49.

Ghani, A. 2003. Medicinal plants of Bangladesh: chemical constituents and uses, Asiatic society of Bangladesh, 138, 1-16.

Jowell, T. (!999). House of Commons official report (Hansard). Herbal medicines, 26, 426-427

Kalgo, M.U., Hamid, K.M., Muhammad, U.A., Balarabe, A., Yeldu, M.H., Yahaya, I.S., Kalgo, Z.M., Aliyu, B., Bala, Y.G. (2019). Effects of Aqueous Stem Bark Extract of Vitellaria paradoxa on Human Neutrophil Function and Viability. International Journal of Biological and Medical Research, 10(3), 6782-6787.

Kalgo, M.U., Hamid, K.M., Balarabe, A., Muhammad, U.A., Bala, Y.G., Raji, H.Y., Yusuf, A., Isiyaku, A., Bagudo, I.A., Usman, A. (2020). Cytotoxic Effect of Aqueous Stem Bark Extract of Vitellaria paradoxa on Human Peripheral Blood Mononuclear Cells. IOSR Journal of Dental and Medical Sciences, 19(2 Ser.4), 48-52

Kangiwa, M.A., Nnaemeka, A.M., Oluwabusuyi, O.J., Bailade, T.E., Oluchi, O.-N.D., lyioku, U.U. (2017). Effects of Cassia occidentalis on Inflammatory cells of Wister Rats Infected with Salmonella Typhi. Annals of Medical Laboratory Science, 1(1), 1-14.

Koffuor, G.A., Abruquah, A.A., Audu, R., Amoah, J., Agwah, D. (2016). Patronage and perceived efficacy of herbal antityphoid preparations, and anti-Salmonella activity of a herbal preparation used in Ghana. Journal of applied pharmaceutical science, 6(3), 1-7.

Kruger, P., Saffarzadeh, M., Weber, A.N., Rieber, N., Radsak, M., Von Bernuth, H., Benarafa, C., Roos, D., Skokowa, J., Hartl, D. (2015). Neutrophils: between host defence, immune modulation, and tissue injury. PLOS Pathogens, 11(3), e1004651.

Lombardo, M., Kiyota, S., Kato, E.T.M., Mathor, M.B., Pinto, T.D.J.A., Kaneko, T.M. (2015). Evaluation of in vitro biological properties of Senna occidentalis (L.) Link. Acta Scientiarum. Biological Sciences, 37(1), 9-13.

Mainasara AS, Oduola T, Musa U, Mshelia AS, Muhammed OA, Ajayi AS. (2011). Effect of Vitellaria paradoxa Stem Bark Ingestion on Kidney Functions in Wistar Rats; British Journal of Pharmacuetical Research, 1(2), 1-8.

Naga, P., Rajeshwari, P. (2014). An overview on immunomodulators. International Journal of Current Pharmaceutical and Clinical Research, 4(2), 108-114.

Niles, A. L., Moravec, R. A., Eric Hesselberth, P., Scurria, M. A., Daily, W. J., and Riss, T. L. (2007). A homogeneous assay to measure live and dead cells in the same sample by detecting different protease markers. Analytical Biochemistry 366(2): 197-206.

Patil, J., Jalalpure, S., Hamid, S., Ahirrao, R. (2010). In-vitro Immunomodulatory Activity of extracts of Bauhinia vareigata Linn bark on Human Neutrophils. Iranian Journal of Pharmacology and Therrapeutics, 9(2) 41-46.

Rahman, M.S., Moly, N.N., Hossen, M.J. (2013). Antimicrobial, Cytotoxic and Antioxidant Activity of The Exudate of Calotropis gigantea. International Journal of Pharmaceutical Sciences and Research, 4(2), 745.

Rekha, U., Thomas, J., Thomas, V., Tiju, J., Prakash, P., Latha, M. (2016). Therapeutic potential of the phytochemicals in Cassia occidentalis-a review. European Journal of Pharmaceutical and Medical Research, 3(9), 180-188.

Sadiq, I.S., Shuaibu, M., Bello, A.B., Tureta, S.G., Isah, A., Izuagie, T., Nasiru, S., Kamaru, M.B. (2012). Phytochemistry and antimicrobial activities of Cassia occidentalis used for herbal remedies. Journal of Chemical Engineering, 1(1), 38-41.

www.ujmr.umyu.edu.ng 
UJMR, Volume 6 Number 2, December, 2021, pp 30 - $36 \quad$ ISSN: 2616 - 0668

Shah, A., Marwat, S., Gohar, F., Khan, A., Bhatti, K., Amin, M., Din, N., Ahmad, M., Zafar, M. (2013). Ethnobotanical study of medicinal plants of semi-tribal area of Makerwal and Gulla Khel (lying between Khyber Pakhtunkhwa and Punjab Provinces), Pakistan. American Journal of Plant Sciences, 4(1), 98-116.

Shanmugam, S., Thangaraj, P., Dos Santos Lima, B., Trindade, G.G.G., Narain, N., Mara De Oliveira, E.S.A., Santin, J.R., Broering, M.F., Serafini, M.R., Quintans-Júnior, L.J., Antunes De Souza Araújo, A. (2020). Protective effects of flavonoid composition rich $P$. subpeltata Ortega. on indomethacin induced experimental ulcerative colitis in rat models of inflammatory bowel diseases. Journal ethnopharmacology, 248, 112350.

Silva, R.O., Sousa, F.B.M., Damasceno, S.R., Carvalho, N.S., Silva, V.G., Oliveira, F.R.M., Sousa, D.P., Aragão, K.S., Barbosa, A.L., Freitas, R.M. (2014). Phytol, a diterpene alcohol, inhibits the inflammatory response by reducing cytokine production and oxidative stress. Fundamental and clinical pharmacology, 28(4), 455-464.

Sini, K., Karpakavalli, M., Sangeetha, P. (2010). Analgesic and antipyretic activity of Cassia occidentalis Linn. World Applied Sciences Journal, 11(10), 1216-1219.

Srivastava, S. K., Xiao, D., Lew, K. L., Hershberger, P., Kokkinakis, D. M., Johnson, C. S., Trump, D. L., and Singh, S. V. (2003). Allyl isothiocyanate, a constituent of cruciferous vegetables, inhibits growth of PC-3 human prostate cancer xenografts in vivo. Carcinogenesis, 24(10), 1665-1670.

Sudeep, N., Nithya, M., Kiranmayee, P. (2017). Evaluation of in vitro cytotoxic effects of three medicinal plants on peripheral blood mononuclear cells (PBMCs). Journal of chemical and pharmaceutical research, 9, 18-26.

Teixeira, R.D.O., Camparoto, M.L., Mantovani, M.S., Vicentini, V.E.P. (2003). Assessment of two medicinal plants, Psidium guajava L. and Achillea millefolium L., in in vitro and in vivo assays. Genetics and Molecular Biology, 26(4), 551-555.

Tochukwu, N., Kenneth, A., Somadina, O., Chukwuebuka, N., Chigozie, I. (2018). Curative and Protective Efficacy of Cassio occidentalis Ethanolic Leaf Extract on Carbon Tetrachloride Induced Liver Damage of Female Albino Wistar Rats. EC Clinical and Experimental Anatomy, 1(2018), 48-61.

Vijayabhaskar, K., Chaitanyaprasad, K., Srisailam, K., Arunadevi, N.M., Swathi, S., Subhashini, P. (2013). Analgesic and anti-inflammatory activities of the extract of Cassia occidentalis (Linn.) animal model. International journal of research in pharmacy and chemistry, 3(4), 759-762.

Vijayalakshmi, S., Lingam, R., Rajeswari, D., Bhagiyalakshmi, M. (2013). Pharmacological profile of Cassia occidentalis L - A review. International Journal of Pharmacy and Pharmaceutical Sciences, 5, 29-33.

Yadav, J.P., Arya, V., Yadav, S., Panghal, M., Kumar, S., Dhankhar, S. (2010). Cassia occidentalis $L$. A review on its ethnobotany, phytochemical and pharmacological profile. Fitoterapia, 81(4), 223-230

Yakubu, M., Akanji, M., Oladiji, A. (2007). Hematological evaluation in male albino rats following chronic administration of aqueous extract of Fadogia agrestis stem. Pharmacognosy Magazine, 3(9), 34-38. 